\title{
Influence of Balloon Pressure Inflation in Patients Undergoing Primary Coronary Stent Implantation during Acute Myocardial Infarction. A Quantitative Coronary Angiography Analysis
}

\author{
Luiz Alberto Mattos, Amanda G.M.R. Sousa, Áurea Chaves, Fausto Feres, Ibraim Pinto, \\ Luiz Tanajura, Marinella Centemero, Alexandre Abizaid, Ana C. Seixas, Andréa Abizaid, \\ Galo Maldonado, Rodolfo Staico, J. Eduardo M.R. Sousa
}

São Paulo, SP - Brazil

\begin{abstract}
Objective - To verify the influence of moderate- or high-pressure balloon inflation during primary coronary stent implantation for acute myocardial infarction.

Methods - After successful coronary stent implantation, 82 patients were divided into 2 groups according to the last balloon inflation pressure: group $1(\geq 12$ to $<16$ atm) and group 2 ( $\geq 16$ to $20 \mathrm{~atm})$, each with 41 cases. All patients underwent late coronary angiography.

Results - In group 1, the mean stent deployment pressure was $13.58 \pm 0.92 \mathrm{~atm}$, and in the group 2 it was $18.15 \pm 1.66 \mathrm{~atm}$. Stents implanted with moderate pressures $(\geq 12$ to $<16$ atm) had a significantly smaller postprocedural minimal lumen diameter, compared to with

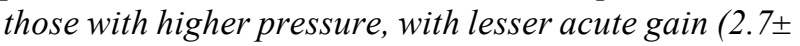
$0.4 \mathrm{~mm}$ vs $2.9 \pm 04 \mathrm{~mm} ; p=0.004)$, but the late lumen loss $(0,9 \pm 0,8 \mathrm{~mm}$ vs $0,9 \pm 0,6 \mathrm{~mm})$ and the restenosis $(22 \%$ vs. $17.1 \%)$ and target-vessel revascularization rates $(9.8 \% \mathrm{vs}$ 7.3\%) were similar between the groups.
\end{abstract}

Conclusion - During AMI stenting, the use of high pressures ( $\geq 16 \mathrm{~atm})$ did not cause a measurable improvement in late outcome, either in the late loss, its index, and the net gain, or in clinical and angiographic restenosis rates.

Key-words: acute myocardial infarction, stents, restenosis

Instituto Dante Pazzanese de Cardiologia

Mailing address: Luiz Alberto Mattos - Av. Jandira, 550/121 - 04080-003 - São Paulo, SP, Brasil - E-mail: pivmattos@uol.com.br
Many clinical, angiographical, and procedural variables are related to the occurrence of in-stent restenosis. Among them, there is the influence of balloon pressure inflation, especially when high pressures were used $(\geq 16 \mathrm{~atm})^{1-6}$. Highpressure balloon inflations (>12 atm) are necessary to promote optimal stent implantation, but they can cause excessive tissue growth repair, with consequent higher rates of restenosis and new target-vessel revascularization ${ }^{7-11}$. Animal studies have already demonstrated the occurrence of this phenomenon, and this was also observed in clinical investigations with intravascular ultrasound monitoring 9,12-14 .

In primary percutaneous coronary intervention, during acute myocardial infarction (AMI), the use of highpressure balloon inflations ( $\geq 16 \mathrm{~atm}$ ) has been recommended ${ }^{15-17}$. However, in the Stent Primary Angioplasty in Myocardial Infarction (PAMI) trial, this routine was one the reasons used to justify the degradation of epicardial coronary flow ${ }^{15,17,18}$. Otherwise, in the same trial, the authors demonstrated that primary coronary stent implantation with low-pressure inflation $(<11 \mathrm{~atm})$ was an unsafe strategy, resulting in higher death rates ${ }^{19}$.

Comparative studies between different ranges of balloon-pressure inflations used for coronary stenting, are sparse, without homogenous data, and with controversial results, and are rare regarding AMI patients ${ }^{20-26}$.

The objective of this analysis was to verify whether moderate pressure inflations (12 to $15 \mathrm{~atm}$ ) promote similar acute lumen gain to that in high-pressure (16 to $20 \mathrm{~atm}$ ), without significant modification in the clinical and angiographic restenosis rates.

\section{Methods}

The patients were included in a consecutive and prospective way (07/1998 to $01 / 2001)$. The inclusion criteria 
were the diagnosis of acute myocardial infarction $(\leq 12$ hours of chest pain with ST segment elevation $\geq 1 \mathrm{~mm}$ in contiguous EKG leads), with primary (without previous fibrinolytic therapy) coronary stent implantation, in patients of both sexes, with ages ranging from 18 to 80 years old. Patients were excluded if they were pregnant, had renal failure (creatinine $\geq 2.0 \mathrm{mg} / \mathrm{dL}$ ), or a previous history of neutropenia, thrombocytopenia, hepatic failure, percutaneous coronary intervention ( $<30$ days), a culprit vessel with a reference diameter less than $<2.5 \mathrm{~mm}$ or target-lesion length greater than $35 \mathrm{~mm}$ (with more than 2 stents). Patients were also excluded if they had a coil or a selfexpanding stent. All patients or their legal representative read and signed the inform consent of the study.

In table I, we describe the adjunctive pharmacology regimen. Abciximab was administered only in the catheterization laboratory according to the following criteria: persistent TIMI-2 flow in the culprit vessel or a great amount of intracoronary thrombus after balloon predilation or procedures performed in high-risk patients (Killip class IV).

The coronary angiography used the Judkins technique, with catheter size ranging from 6 to $8 \mathrm{~F}$ and ionic contrast. The coronary arteries were visualized in at least 2 orthogonal projections. Significant coronary heart disease was considered present when diameter stenosis was $=50 \%$, determined by quantitative coronary angiography analysis. The left ventricular angiogram was performed in a right anterior oblique projection. All stents were implanted with previous balloon predilation ( 6 to $10 \mathrm{~atm}$ ). Only the infarctrelated artery was treated with coronary stenting ${ }^{27}$.

All the implanted stents were premounted. The final balloon-pressure inflation was performed with the same balloon used for delivering the stent, or at operator discretion, an additional balloon was used, following a balloon/artery ratio $\geq 1$. The final pressure used in the procedure was noted and used to divide the patients into 2 groups ( 12 to 20 $\mathrm{atm})$. The final goal was the obtainment of optimal stent implantation defined by a residual stenosis $\leq 10 \%$, without edge dissections or the persistent presence of intracoronary thrombus in the target vessel.

After hospital discharge, patients were followed according to a routine: clinical on-site visit after 180 days from the index procedure for symptom evaluation, and performance of a new electrocardiogram and functional tests, if they were necessary. A new coronary angiography was performed in all patients independently from the presence of anginal symptoms, in a period of $\geq 6$ to $\leq 12$ months. A coronary angiography performed before this period was considered valid for the study if an in-stent restenosis was confirmed ( $\% \mathrm{E} \geq 50 \%)$. A new target-vessel revascularization was performed only if it was ischemia-driven and associated with the presence of severe in-stent restenosis. All new percutaneous and surgical procedures were counted, either for target and nontarget vessels.

All the changes in lumen size were measured by offline quantitative coronary angiography [CMS-Medis ${ }^{\circledR}(\mathrm{Car}-$ diovascular Measurement System) da Medical Imaging Systems $^{\circledast}{ }^{28,29}$. The frames were analyzed either on cine films or compact discs. The automatic edge detection method was used for that purpose, according to the reference size of the guiding catheter used in the procedure (userdefined). The measurements were performed pre- and poststent implantation and at the late follow-up. The reference diameter was the average between the proximal and distal size of the vessel, when the target vessel was completely occluded. In the event of an occlusion, only the proximal measurement was used. The luminal changes measured were $:$ acute gain [minimal luminal diameter(MLD post-MLD pre)], late loss (MLD post-MLD follow-up), net gain (acute gain - late loss) and late loss index (late loss acute gain). All these luminal changes were corrected by the reference diameter (relative value), either poststent (acute gain) or at the follow-up (late loss) ${ }^{11,30}$. The measurements were performed in a blinded manner. An experienced physician, aware of the purpose of the study, performed the measurements.

A comparative analysis was performed dividing the pa-

\begin{tabular}{|c|c|c|c|c|}
\hline Place Drug & Emergency Room & Cath Lab & Intensive Coronary Care Unit & At Discharge \\
\hline Aspirin & $200 \mathrm{mg}$; chewable & No & $200 \mathrm{mg} / \mathrm{PO} /$ day & $\begin{array}{l}200 \mathrm{mg} / \mathrm{PO} / \text { day; } \\
\text { indefinitely }\end{array}$ \\
\hline Ticlopidine & $\begin{array}{l}250 \mathrm{mg} / \mathrm{PO} \\
12 / 12 \mathrm{~h}\end{array}$ & No & $\begin{array}{l}250 \mathrm{mg} / \mathrm{PO} \\
12 / 12 \mathrm{~h}\end{array}$ & $\begin{array}{l}250 \mathrm{mg} / \mathrm{PO} \\
12 / 12 \mathrm{~h} / 30 \text { days }\end{array}$ \\
\hline Metropolol * & $15 \mathrm{mg} \mathrm{IV}$ & No & No & No \\
\hline Atenolol & No & No & $25-100 \mathrm{mg} / \mathrm{PO} /$ day & $25-100 \mathrm{mg} / \mathrm{PO} /$ day \\
\hline Unfractionated heparin & No & $10.000 \mathrm{IU} / \mathrm{IV} * *$ & $\begin{array}{l}1.000 \mathrm{IU} / \mathrm{h} / 48 \mathrm{~h} \\
\text { (ACT } 200 \text { to } 300 \mathrm{~s} \text { ) }\end{array}$ & No \\
\hline Abciximab & No & $\begin{array}{l}\text { IV bolus } \\
0,25 \mathrm{mg} / \mathrm{kg}\end{array}$ & $\begin{array}{l}0,125 \mathrm{mcg} / \mathrm{kg} / \mathrm{min} / 12 \mathrm{~h} \text {, } \\
\mathrm{IV} \text {, without IV heparin }\end{array}$ & No \\
\hline Nitroglycerin & No & $0,2 \mathrm{mg}$ intracoronary & No & No \\
\hline Nitrates & $5 \mathrm{mg} \mathrm{SL}$ & No & No & No \\
\hline Captopril *** & No & No & $50-150 \mathrm{mg} / \mathrm{PO} /$ day & $50-150 \mathrm{mg} / \mathrm{PO} /$ day \\
\hline
\end{tabular}


tients into 2 groups, according to the final stent pressure used: [group 1 ( $\geq 12$ to $<16 \mathrm{~atm}$ ) and group 2 ( $\geq 16$ to $20 \mathrm{~atm})$ ]. The primary end-point was the measurement of the acute gain, late loss, and the loss index. The secondary objectives were the infarct-related artery patency, classification of the epicardial coronary flow (TIMI classification) ${ }^{31}$, in-stent restenosis, reocclusion, and target-vessel revascularization rates.

The sample size was estimated according to previous findings obtained from the elective coronary stent implantation study ${ }^{25}$. It was confirmed that a late loss index of 0.5 was expected when high pressures were used ( $\geq 16$ to $\leq 20 \mathrm{~atm}$ ). A $30 \%$ reduction in the late loss index was estimated $(80 \%$ power) if lower pressure was used ( $\geq 12$ to $<16$ atm). Fortyone patients were necessary in each group. Assuming that at least $85 \%$ of patients would return for a new coronary angiography, 95 patients would be necessary. The continuous variables were shown by averages with their standard deviation. The differences between them were analyzed with the Student $t$ test. The continuous variables were displayed in absolute numbers with their respective percentage $(\%)$, and their differences verified with the chisquare or Fisher exact tests, when necessary. The software used was SPSS $^{\circledR}$ for Windows ${ }^{\circledR}\left(\right.$ Microsoft $\left.^{\circledR}\right)$ version 9.0. Statistical significance was considered as $\mathrm{p} \leq 0.05$.

\section{Results}

Nighty-five patients were included for this analysis. Thirteen (13.7\%) did not undergo a new coronary angiography and were excluded from the analysis. The reasons were absence of a clinical follow-up visit or request for rescheduling of the coronary angiography for a period longer than that stipulated by the protocol (6 patient), refusal to undergo a new coronary angiography (2), stroke during the follow-up period (1), pregnancy (1), progressive renal failure (1), severe ostio-articular disease (1), and diagnosis of malignancy (1). Table II displays the demographics of patients included and excluded from the study. No statistical differences existed between them. Eighty-two patients were then included, 41 in each group. Figure 1 displays the recruitment of patients during this period. Patients were allocated more frequently into the group 2 in the first 6 months and into group 1 more frequently in the last 13 months.

The clinical profile is provided in table III. The clinical profiles between groups were similar. The majority were males, $15 \%$ had diabetes, and both groups had similar rates of anterior and inferior wall myocardial infarction.

The angiographic characteristics are demonstrated in table IV. The left ventricular ejection fraction was significantly reduced in group 1 compared with that in group 2 patients $(42.9 \pm 11.1 \%$ vs $49.1 \pm 11.4 \%$; $\mathrm{p}=0.02)$. The presence of multivessel coronary heart disease was common (63.4\%), and $17.1 \%$ of patients exhibited triple-vessel disease.

Table $\mathrm{V}$ provides an analysis of the procedural profile of the patients. All the stent types were similar between the groups $(\mathrm{p}=0.37)$. Six physicians performed the procedures.
An analysis of the results according to the different operators was not performed.

The mean stent pressure inflation was $15.9 \pm 2.6 \mathrm{~atm}$. In group 1, the average was $13.6 \pm 0.9 \mathrm{~atm}$ and in the group 2, $18.1 \pm 1.7 \mathrm{~atm}$. In patients included in group 2, more stents were implanted per vessel treated $(1.2 \pm 0.4$ vs $1.1 \pm 0.2$; $\mathrm{p}=0.04)$. Two stents were implanted in 10 patients $(12.2 \%)$. Of these, 2 were in group 1, and 8 were in group $2(4.9 \%$ vs $19.5 \% ; \mathrm{p}=0.04)$. The patients in group 2 had larger reference diameters of the target vessel $(3.3 \pm 0.3 \mathrm{~mm}$ vs $3.2 \pm 0.3 \mathrm{~mm}$; $\mathrm{p}=0.047$ ), and the balloon achieved bigger diameters $(3.5 \pm 0.4 \mathrm{~mm}$ vs $3.3 \pm 0.3 \mathrm{~mm} ; \mathrm{p}=0.007)$, when compared with those in group 1. Otherwise, patients in group 1 received abciximab infusion more frequently than did those in group $2(39 \%$ vs $17.1 \%$; $=0.048)$ (tab. V).

Epicardial coronary flow was verified according to TIMI classification (tab. VI). No statistical differences existed between groups.

All 82 patients underwent a new coronary angiography at a similar follow-up time $(214.4 \pm 72.7$ days vs $199.1 \pm$ 49.9 days; $p=0.27$ ) (tab. VII). The number of asymptomatic patients were the same for both groups $(75.6 \%)$, as was that of patients with unstable angina $(2.4 \% ; \mathrm{p}=0.25)$. No reinfarctions occurred during follow-up. A new target-vessel revascularization procedure were necessary in $8.5 \%$ of the 82 patients, but without a statistical difference between groups $(9.8 \%$ vs $7.2 \%$; $=0.17)$. Regarding nontarget-vessel revascularization, no differences occurred between the groups $(19.5 \%$ vs $17.1 \%$; $\mathrm{p}=0.77)$. The total new revascularizations procedures performed in all these patients was $26.8 \%$ (group $1,29.3 \%$ vs group $2,24.4 \%$; $\mathrm{p}=0.62$ ) (tab. VII).

The quantitative coronary angiography analysis showed (tab. VIII) that the balloon to artery ratio was similar in both groups $(1.1 \pm 0.1$ vs $1.1 \pm 0.1 ; \mathrm{p}=0.65)$. In group 1 , smaller arteries were treated, according to the reference diameter after stent implantation, when compared with arteries in group $2(3.1 \pm 0.3 \mathrm{~mm}$ vs $3.3 \pm 0.4 \mathrm{~mm}$; $\mathrm{p}=0.02)$. However, the reference diameter measurement showed only

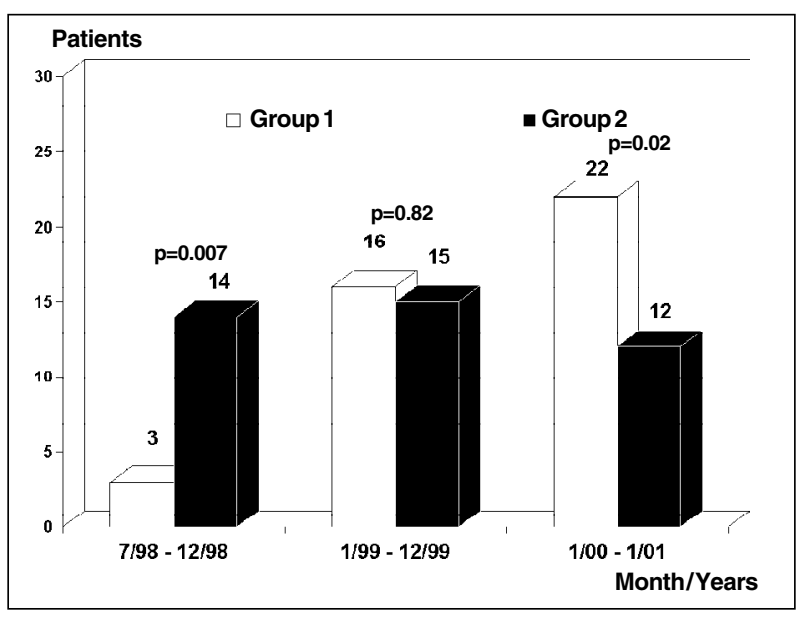

Fig. 1 - Temporal recruitment of patients for the investigation. divided according to the coronary stent implantation pressure [group 1 ( $\geq 12 \mathrm{a}<16 \mathrm{~atm})$ and group $2(\geq 16$ $\mathrm{a} \leq 20 \mathrm{~atm}$ )] 


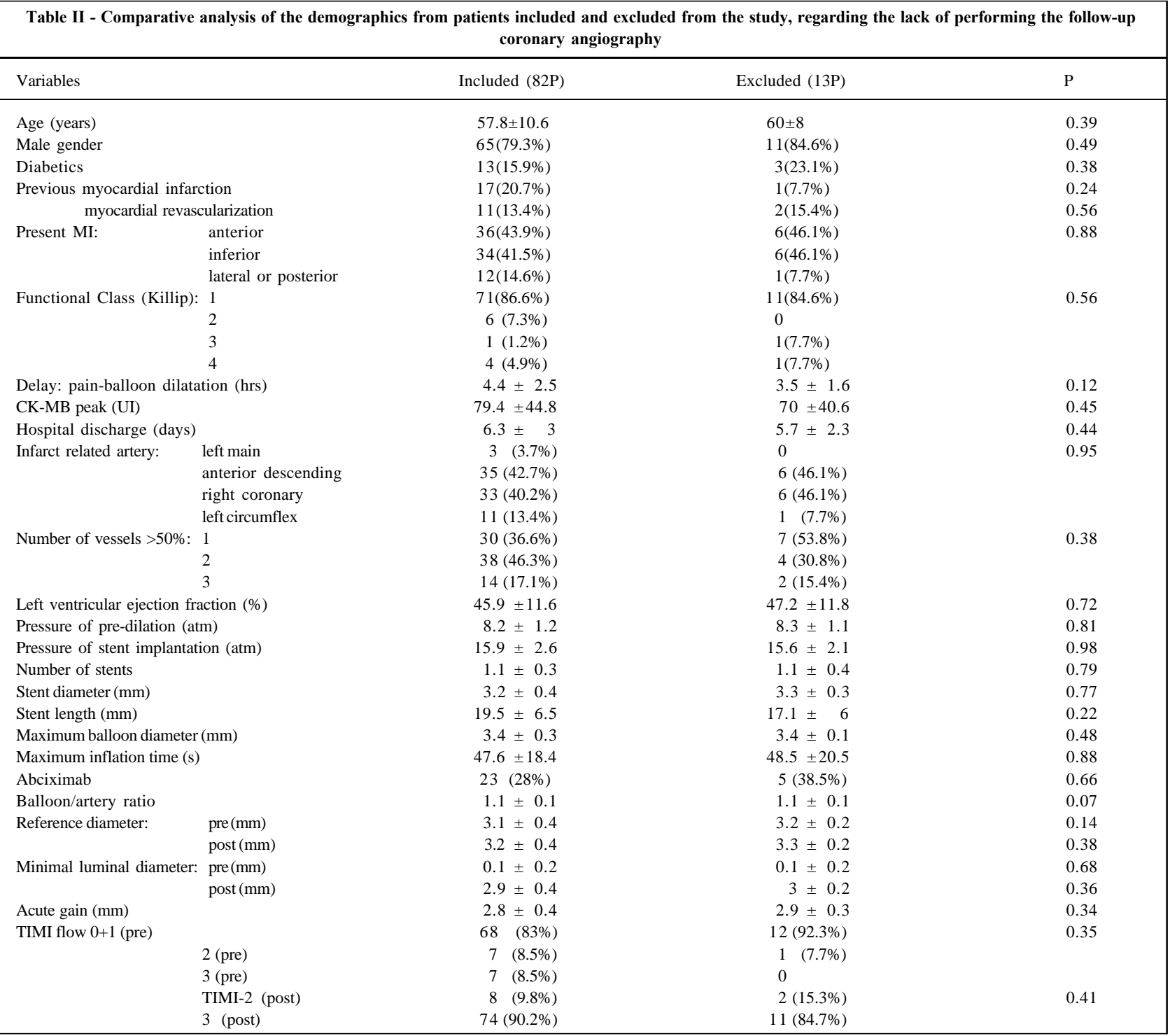

a tendency toward this, when we analyzed the prestent values and at follow-up (pre: $3 \pm 0.3 \mathrm{~mm}$ vs $3.1 \pm 0.4 \mathrm{~mm}$; $\mathrm{p}=0.06$, and follow-up: $3.1 \pm 0.3 \mathrm{~mm}$ vs $3.2 \pm 0.4 \mathrm{~mm} ; \mathrm{p}=0.07$, group 1 and 2, respectively). The patients in group 1 had a significantly smaller MLD poststent when compared with group $2(2.8 \pm 0.3 \mathrm{~mm}$ vs $3 \pm 0.4 \mathrm{~mm} ; \mathrm{p}=0.001)$, but in the follow-up, no statistical differences existed between them $(1.9 \pm 0.9 \mathrm{~mm}$ vs $2.1 \pm 0.8 \mathrm{~mm} ; \mathrm{p}=0.26)$. The percentage of the diameter stenosis in the target vessel followed the findings according to the MLD changes [prestent $(96.6 \pm 7.9 \%$ vs $96.8 \pm 7.4 \%$; $\mathrm{p}=0.90)$; poststent $(11.6 \pm 5.3 \%$ vs $8.7 \pm 5.4 \%$; $\mathrm{p}=0.02)$ and follow-up $(38.7 \pm 26 \%$ vs $35.4 \pm 21.1 \% ; \mathrm{p}=0.53)$ ], group 1 vs group 2 .

In group 1, the acute luminal gain was significantly less compared with that in group $2(2.7 \pm 0.4 \mathrm{~mm}$ vs $2.9 \pm 0.4$ $\mathrm{mm} ; \mathrm{p}=0.004)$, but the late loss was similar $(0.9 \pm 0.8 \mathrm{~mm}$ vs $0.9 \pm 0.6 \mathrm{~mm} ; \mathrm{p}=0.73)$, as was the net gain $(1.8 \pm 0.9 \mathrm{~mm}$ vs $2 \pm 0.8 \mathrm{~mm} ; \mathrm{p}=0.24)$ and the late loss index $(0.3 \pm 0.3$ vs $0.3 \pm 0.2$; $\mathrm{p}=0.93$ ). The relative values were not significantly different when both groups where compared (tab. VIII and fig. 2). The in-stent restenosis rate was $22 \%$ (group 1) and $17.1 \%$ (group $2 ; \mathrm{p}=0.69)$, respectively.

The late angiographic analysis of the global ejection fraction demonstrated a significant recovery in both groups. The mean percentage gain was $6.8 \pm 2.9 \%$ for group 1 patients ( $49.1 \pm 11.4 \%$ vs $55.9 \pm 11.9 \%$; $=0.01$ ), and of $5.7 \pm 3.1 \%$, for group 2 patients $(42.9 \pm 11.1 \%$ vs $48.6 \pm 13.7 \%$; $\mathrm{p}=0.047$ ).

\section{Discussion}

The late follow-up results of the 82 patients who underwent primary coronary stenting during AMI, either clinical or angiographic, were similar independently of the different ranges of stent pressure inflation ( $\geq 12$ to $<16$ and $\geq 16$ to $\leq 20 \mathrm{~atm}$ ).

The group 2 patients, who underwent stent implantation with high-pressure balloon inflation, obtained a significantly higher acute lumen gain ( $2.9 \pm 0.4$ vs $2.7 \pm 0.4 \mathrm{~mm}$; $\mathrm{p}=0.004)$. However, after the correction for the index value 


\begin{tabular}{|c|c|c|c|}
\hline \multicolumn{4}{|c|}{$\begin{array}{l}\text { Table III - Clinical profile from the } 82 \text { patients who underwent } \\
\text { primary coronary stent implantation, divided according to the } \\
\text { coronary stent implantation pressure }\end{array}$} \\
\hline Variables & Group $1(41 \mathrm{P})$ & Group $2(41 \mathrm{P})$ & $\mathrm{p}$ \\
\hline Age (years) & $58.9+11.3$ & $56.7+10.1$ & 0.36 \\
\hline Range & 28 to 79 & 37 to 77 & - \\
\hline Male gender & $30(73.2 \%)$ & $35(85.4 \%)$ & 0.28 \\
\hline Diabetics & $5(12.2 \%)$ & $8(19.5 \%)$ & 0.55 \\
\hline Hypertension & $23(56.1 \%)$ & $24(58.5 \%)$ & 1 \\
\hline Smokers & $31(75.6 \%)$ & $28(68.3 \%)$ & 0.62 \\
\hline \multicolumn{4}{|l|}{ Previous events } \\
\hline Myocardial infarction & $10(24.4 \%)$ & $7(17.1 \%)$ & 0.59 \\
\hline Percutaneous intervention & $3(7.3 \%)$ & $2(4.9 \%)$ & 1 \\
\hline Surgical revascularization & $4(9.8 \%)$ & $2(4.9 \%)$ & 0.67 \\
\hline Present myocardial infarction & & & 0.41 \\
\hline Anterior & $16(39 \%)$ & $20(48.8 \%)$ & \\
\hline Inferior & $17(41.5 \%)$ & $17(41.5 \%)$ & \\
\hline Lateral or posterior & $8(19.5 \%)$ & $4(9.8 \%)$ & \\
\hline Functional class (Killip) & & & 0.20 \\
\hline 1 & $36(87.8 \%)$ & $35(85.4 \%)$ & \\
\hline 2 & $1(2.4 \%)$ & $5(12.2 \%)$ & \\
\hline 3 & $1(2.4 \%)$ & 0 & \\
\hline 4 & $3(7.3 \%)$ & $1(2.4 \%)$ & \\
\hline $\begin{array}{l}\text { Delay: pain-balloon dilatation } \\
\text { (hrs) }\end{array}$ & $4.4 \pm 2.4$ & $4.4 \pm 2.5$ & 0.96 \\
\hline CK-MB peak (UI) & $86.1 \pm 42.9$ & $73.7 \pm 46.3$ & 0.28 \\
\hline Hospital discharge (days) & $6.4 \pm 3.2$ & $6.1 \pm 2.9$ & 0.75 \\
\hline
\end{tabular}

(reference diameter), the acute gain became similar between groups (group 1: $0.8 \pm 0.1$ vs group $2: 0.9 \pm 0.1 ; p=0.13$ ). The other quantitative angiographic variables also did not differ when the comparison was performed, either in the follow-up $\operatorname{MLD}(1.9 \pm 0.9 \mathrm{~mm}$ vs $2.1 \pm 0.8 \mathrm{~mm} ; \mathrm{p}=0.26)$, the late loss $(0.9 \pm 0.8 \mathrm{~mm} v \mathrm{~s} 0.9 \pm 0.6 \mathrm{~mm} ; \mathrm{p}=0.73)$, thenet gain $(1.8 \pm 0.9 \mathrm{~mm}$ vs $2 \pm 0.8 \mathrm{~mm} ; \mathrm{p}=0.24)$ and their relative value $(0.6 \pm 0.3$ versus $0.6 \pm 0.2 ; \mathrm{p}=0.50)$. The same finding was observed regarding the late loss index of the target vessel $(0.3 \pm 0.3$ vs $0.3 \pm 0.2$; $\mathrm{p}=0.93$ ).

The secondary end points were similar between the different strategies of primary coronary stent implantation

\begin{tabular}{|c|c|c|c|}
\hline $\begin{array}{r}\text { Table IV - Angiographic pro } \\
\text { primary coronary stent } \\
\text { coronary ste }\end{array}$ & $\begin{array}{l}\text { file from the } 82 \\
\text { mplantation, div } \\
\text { nt implantation }\end{array}$ & $\begin{array}{l}\text { patients who und } \\
\text { ided according to } \\
\text { pressure }\end{array}$ & $\begin{array}{l}\text { erwent } \\
\text { the }\end{array}$ \\
\hline Variables & Group $1(41 \mathrm{P})$ & Group 2 (41P) & $\mathrm{p}$ \\
\hline Infarct related artery & & & 0.14 \\
\hline Left main & $3(7.3 \%)$ & 0 & \\
\hline Anterior descending & $15(36.6 \%)$ & $20(48.8 \%)$ & \\
\hline Right coronary & $16(39.1 \%)$ & $17(41.4 \%)$ & \\
\hline Left circumflex & $7(17 \%)$ & $4(9.8 \%)$ & \\
\hline Total & $41(100 \%)$ & $41(100 \%)$ & \\
\hline Number of vessels with $\geq 50 \%$ & & & 0.62 \\
\hline 1 & $13(31.7 \%)$ & $17(41.5 \%)$ & \\
\hline 2 & $21(51.2 \%)$ & $17(41.5 \%)$ & \\
\hline 3 & $7(17.1 \%)$ & $7(17.1 \%)$ & \\
\hline Coronary calcification & $11(26.8 \%)$ & $9(21.9 \%)$ & 0.61 \\
\hline $\begin{array}{l}\text { Left ventricular ejection } \\
\text { fraction }(\%)\end{array}$ & $49.1+11.4 *$ & $42.9+11.1 * *$ & 0.02 \\
\hline
\end{tabular}

(reestablishment of TIMI-3 flow, in-stent restenosis, reocclusion and target-vessel revascularization rates).

Some variables might influence the results of a primary coronary stent procedure. Four of these deserve comments: use of abciximab, the stent type, diabetes, and treatment of restenotic and long lesions.

The patients in group 1 received intravenous infusion of abciximab, a potent inhibitor of IIb/IIIa surface receptors of platelets more frequently, which caused a profound antiplatelet effect. We do not believe that this difference influenced the late angiographic results. Five former studies already demonstrated that abciximab did not cause a significant reduction in stent restenosis rates ${ }^{16,33-35}$. Their advantages are related much more to acute procedural improvements, either in coronary flow (epicardial and in the microcirculation) or in a better recovery of left ventricular function, especially, when it is administered before the procedure begins ${ }^{35}$.

Other procedural differences were observed when both groups were compared. The group 2 patients received more stents per vessel compared with group 1, but the total stent length was similar between groups. This finding is because of the more recent availability of customized sizes for stents (fig. 1) ${ }^{27}$. This fact was strictly related to a temporal trend in stent availability, rather than the occurrence of stent implantation failure in the patients randomized to group 2 (edge dissections). Regarding stent type, no patients received coil or self-expanding stents. All the stent types implanted in this series already had similar clinical and angiographic results in previous head-to-head trials ${ }^{36,37}$.

The fact that more patients in group 2 underwent multiple stent implantation might cause disagreement about its influence in the late angiographic results. Tanajura et $\mathrm{al}^{38} \mathrm{de}-$ monstrated that the implantation of multiple stents per se does not directly influence the follow-up of patients (in-stent restenosis of multiple stents, $29 \%$ versus single stent, $33 \%$; $\mathrm{p}=\mathrm{NS}$ ). Similar to these study, in our study only 2 stents were used. However, a word of caution is necessary, especially about patients who undergo very long stent length implantation (>35 mm): this is an angiographic situation that has a higher expectation of in-stent restenosis ${ }^{38-39}$.

Regarding the implantation of long stents in AMI (>20 $\mathrm{mm}$ ), the Controlled Abciximab and Device Investigation to Lower Late Angioplasty Complications (CADILLAC) study ${ }^{16}$ also determined that the upper limit of stent length should be $35 \mathrm{~mm}$. In the procedural analysis, the mean stent length ${ }^{12}$ was $23 \mathrm{~mm}$ in 1,037 patients treated, with an average of 1.3 stents per vessel. The 6-month target vessel revascularization rates were $7.4 \%$ and $5.0 \%$, considering both randomized groups of stents, with or without abciximab, respectively. In the present investigation, the findings were similar. So, probably the difference in the number of stents used in both groups might not have influenced the final analysis.

The presence of diabetes ${ }^{1,3}$, restenotic lesions ${ }^{1}$, or lesion length also may cause an adverse late result after coronary stenting ${ }^{2,39}$. Neither of these variables was different in either group. The lesion length measurement during AMI 


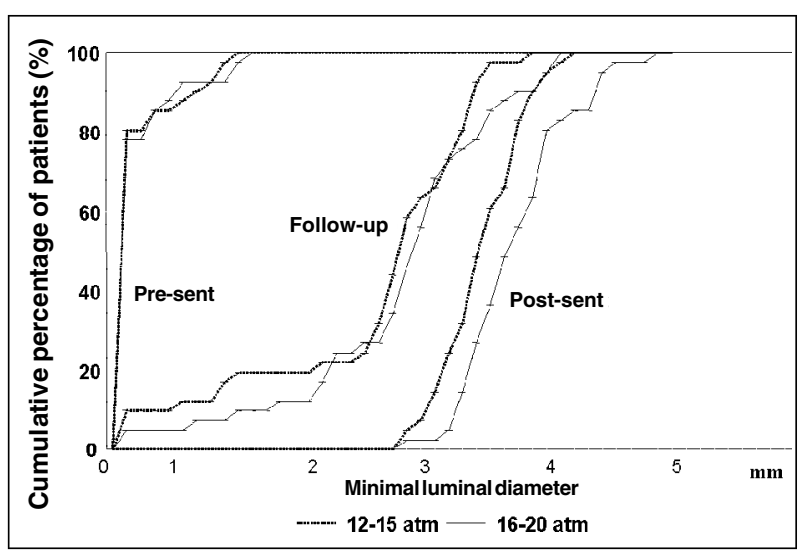

Fig. 2 - Cumulative analysis of the minimal luminal diameter of the 82 patients who underwent primary coronary stent implantation. divided according to the coronary stent implantation pressure.

percutaneous procedures may not be accurate ${ }^{28-30}$. More than $80 \%$ of the infarct-related vessels were initially found to be occluded. All vessels underwent balloon predilation, reestablishing the coronary epicardial flow. After that, a precise measurement of the lesion length is missed, in part, reduced by the balloon effect.

Quantitative coronary angiography with automatic edge detection was used to analyze the luminal changes ${ }^{28-30}$. Since 1994, all randomized series that tested the efficacy of stenting in AMI used the same technique, confirming its accuracy and reproducibility 2,15-18,40-43.

In 1995, Colombo et al ${ }^{10}$ introduced the concept of optimal coronary stent implantation, with high-pressure assisted balloon inflation ( $\geq 12 \mathrm{~atm}$ ). The former studies $9,20,21,26$ that investigated the influence of balloon pressure on late angiographic results after stent implantation used mixed techniques (low and high pressure inflations), and also systematic exclusion of AMI patients from their data. The comparison of this series with these former ones had to be done with caution because of the different strategies used to perform coronary stenting.

The Optimal Stent Implantation Investigators (OSTI) registry very clearly demonstrates the acute mechanism of lumen enlargement related to progressive high-pressure inflations. Seventy-nine patients underwent progressive high-pressure balloon inflations during coronary stenting (12, 15, and $18 \mathrm{~atm})$. The authors verified that the higher the pressure, the bigger the lumen gain achieved. They suggested that stents should be implanted with very high pressures ( $\geq 18 \mathrm{~atm})$, in a systematic manner. However, this registry did not perform late coronary angiography in these patients to verify the possible influence of this strategy in late lumen loss. Probably, they said, smaller vessels should not accommodate the excess of mio-intimal hyperplasia ${ }^{44}$.

Dirschinger et al $^{25}$ examined a randomized series of 933 patients, but again AMI cases were excluded. The patients were divided in a randomized way into 2 groups: one designated as lower pressure, from 8 to $13 \mathrm{~atm}$ (mean $=$ $11.1 \pm 2.1 \mathrm{~atm})$ and the other one as higher pressure, from 15 to $20 \mathrm{~atm}$ (mean $=16.9 \pm 2 \mathrm{~atm})$. They did not find any significant difference in the clinical or angiographical results between these groups of patients (stent thrombosis, AMI, new PTCA, urgent surgery, or death), either in the acute phase [3\% vs $2.8 \%$; OR=0.92(CI=0.4-2.1)], or at 1 -year [24.5\% vs $21.2 \%$; $\mathrm{OR}=0.85(\mathrm{CI}=0.6-1.1)]$. At 6-months, the in-stent restenosis rate was similar in both groups ( $31.4 \%$ vs $30.4 \%$; NS), as was the late loss index $(0.6 \pm 0.5 \mathrm{~mm}$ vs $0.5 \pm 0.4 \mathrm{~mm} ; \mathrm{NS})$. Only the CK-MB measurement was different in both groups, higher $(>3 \mathrm{x})$ in patients who underwent high-pressure inflations $[3.4 \% \text { vs } 6.4 \% ; \mathrm{OR}=1.87(\mathrm{CI}=1.02-3.42)]^{25}$.

Uretsky et al $^{22}$ reported the results of a nonrandomized clinical series comparing very high-pressure stent implantation $(20 \mathrm{~atm})$ with moderate pressures [12 to $19 \mathrm{~atm}($ mean $=$ 14.3 $\pm 2.6 \mathrm{~atm})$ ]. In 136 patients included, again AMI was an exclusion criterion. The acute procedural result was similar between both strategies, but at the 1-year follow-up,

\begin{tabular}{|c|c|c|c|}
\hline \multicolumn{4}{|c|}{$\begin{array}{l}\text { Table V - Procedural data from the } 82 \text { patients who underwent primary coronary stent implantation, divided according to the coronary stent } \\
\text { implantation pressure }\end{array}$} \\
\hline Variables & Group 1 (41P) & Group $2(41 \mathrm{P})$ & $\mathrm{P}$ \\
\hline Pressure of balloon predilation (atm) & $8.1 \pm 1.2$ & $8.3 \pm 1.2$ & 0.52 \\
\hline Range & 6 to 10 & 6 to 10 & - \\
\hline Pressure of stent implantation (atm) & $13.6 \pm 0.9$ & $18.1 \pm 1.7$ & $<0.001$ \\
\hline Number of stents & $1.1 \pm 0.2$ & $1.2 \pm 0.4$ & 0.04 \\
\hline Stent diameter (mm) & $3.2 \pm 0.3$ & $3.3 \pm 0.3$ & 0.047 \\
\hline Stent length $*(\mathrm{~mm})$ & $19.3 \pm 6.4$ & $19.6 \pm 6.6$ & 0.81 \\
\hline Range & 8 até 35 & 15 até 33 & - \\
\hline Stent type $* *$ & & & 0.37 \\
\hline Coris/Johnson\&Johnson ${ }^{\circledR}$ & $10(24.4 \%)$ & $15(36.6 \%)$ & \\
\hline Guidant/ACS $^{\circledR}$ & $16(39 \%)$ & $13(31.7 \%)$ & \\
\hline Medtronic $^{\circledR}$ & $8(19.5 \%)$ & $10(24.4 \%)$ & \\
\hline Boston Scientific/Scimed ${ }^{\circledR}$ & $7(17.1 \%)$ & $3(7.3 \%)$ & \\
\hline Maximum balloon diameter (mm) & $3.3 \pm 0.3$ & $3.6 \pm 0.4$ & 0.007 \\
\hline Maximum inflation time (seconds) & $45 \pm 18.1$ & $50.1 \pm 18.6$ & 0.21 \\
\hline Abciximab & $16(39 \%)$ & $7(17.1 \%)$ & 0.048 \\
\hline
\end{tabular}




\begin{tabular}{|c|c|c|c|}
\hline \multicolumn{4}{|c|}{$\begin{array}{l}\text { Table VI - Epicardial coronary flow, according to the TIMI } \\
\text { classification, from the } 82 \text { patients who underwent primary coronary } \\
\text { stent implantation, divided according to the coronary stent } \\
\text { implantation pressure }\end{array}$} \\
\hline Variables & Group $1(41 \mathrm{P})$ & Group 2 (41P) & $\mathrm{P}$ \\
\hline Pre-procedure & & & 0.058 \\
\hline TIMI-0 & $32(78 \%)$ & $33(80.5 \%)$ & \\
\hline 1 & $2(4.9 \%)$ & $1(2.4 \%)$ & \\
\hline 2 & $6(14.6 \%)$ & $1(2.4 \%)$ & \\
\hline 3 & $1(2.4 \%)$ & $6(14.6 \%)$ & \\
\hline Post-stent & & & 0.71 \\
\hline TIMI-0 & 0 & 0 & \\
\hline 1 & 0 & 0 & \\
\hline 2 & $5(12.2 \%)$ & $3(7.3 \%)$ & \\
\hline 3 & $36(87.8 \%)$ & $38(92.7 \%)$ & \\
\hline Follow-up & & & 0.24 \\
\hline TIMI-0 & $4(9.8 \%)$ & $1(2.4 \%)$ & \\
\hline 1 & 0 & $1(2.4 \%)$ & \\
\hline 2 & 0 & 0 & \\
\hline 3 & $37(90.2 \%)$ & $39(95.1 \%)$ & \\
\hline
\end{tabular}

patients in whom the $20 \mathrm{~atm}$ was used had a higher rate of clinical composite adverse events ( $9.5 \%$ vs $28.8 \%$; $\mathrm{p}=0.005$ ), related to a higher rate of new target-vessel revascularization (5\% vs $20 \%$; $\mathrm{p}=0.009)^{22}$.

These findings should be replicated in the AMI scenario ${ }^{15,16}$. The subanalysis from the STENT PAMI trial ${ }^{19}$ gathered 508 patients divided into 6 groups according to the final pressure used for stent implantation (from 8 to $20 \mathrm{~atm}$ ). The authors demonstrated that in 90 patients $(17.7 \%$ of the total) that finalized the procedure with lower pressures ( 8 to $11 \mathrm{~atm})$, the 30-day mortality rate was significantly higher $(10.1 \%$ vs $2.1 \%$; $p<0.02)$ compared with that with high-pressure inflations ( $>11 \mathrm{~atm})$. Using lower pressures constituted an independent predictor of higher mortality $[\mathrm{p}=0.002$; $\mathrm{RC}=5.07(\mathrm{IC}=1.90-14.3)]$. Our series had similar late angiographic results when compared with those of STENT PAMI, regarding the late loss index in the target vessel ( 0.3 and 0.4 , respectively). The conclusion was the same: coro-

\begin{tabular}{|c|c|c|c|}
\hline \multicolumn{4}{|c|}{$\begin{array}{l}\text { Table VII - Clinical follow-up of the } 82 \text { patients who underwent } \\
\text { primary coronary stent implantation. divided according to the } \\
\text { coronary stent implantation pressure }\end{array}$} \\
\hline Variables & Group 1 (41P) & Group 2 (41P) & $\mathrm{p}$ \\
\hline \multicolumn{4}{|c|}{ New coronary angiography } \\
\hline Range (days) & 104 to 370 & 100 to 350 & - \\
\hline Symptom & & & 0.25 \\
\hline Asymptomatic & $31(75.6 \%)$ & $31(75.6 \%)$ & \\
\hline Stable angina & $9(22 \%)$ & $9(22 \%)$ & \\
\hline Unstable angina & $1(2.4 \%)$ & $1(2.4 \%)$ & \\
\hline Reinfarction & 0 & 0 & \\
\hline \multicolumn{3}{|c|}{ Target-vessel revascularization } & 0.17 \\
\hline Balloon or new stent & $2(4.9 \%)$ & $2(4.9 \%)$ & \\
\hline Surgery & $2(4.9 \%)$ & $1(2.4 \%)$ & \\
\hline Total & $4(9.8 \%)$ & $3(7.3 \%)$ & \\
\hline \multicolumn{3}{|c|}{ Non target-vessel revascularization } & 0.77 \\
\hline Balloon or new stent & $5(12.1 \%)$ & $6(14.7 \%)$ & \\
\hline Surgery & $3(7.3 \%)$ & $1(2.4 \%)$ & \\
\hline Total & $8(19.5 \%)$ & $7(17.1 \%)$ & \\
\hline
\end{tabular}

\begin{tabular}{|c|c|c|c|}
\hline \multicolumn{4}{|c|}{$\begin{array}{l}\text { Table VIII - Quantitative coronary angiography analysis of the } 82 \\
\text { patients who underwent primary coronary stent implantation. divided } \\
\text { according to the coronary stent implantation pressure }\end{array}$} \\
\hline Variables & Group $1(41 \mathrm{P})$ & Group 2 (41P) & $\mathrm{p}$ \\
\hline Balloon/artery ratio & $1.1 \pm 0.1$ & $1.1 \pm 0.1$ & 0.65 \\
\hline \multicolumn{4}{|l|}{ Reference diameter (mm) } \\
\hline Pre & $3 \pm 0.3$ & $3.1 \pm 0.4$ & 0.06 \\
\hline Post & $3.1 \pm 0.3$ & $3.3 \pm 0.4$ & 0.02 \\
\hline Follow-up & $3.1 \pm 0.3$ & $3.2 \pm 0.4$ & 0.07 \\
\hline \multicolumn{4}{|c|}{ Minimal luminal diameter (mm) } \\
\hline Pre & $0.1 \pm 0.2$ & $0.1 \pm 0.2$ & 0.96 \\
\hline Post & $2.8 \pm 0.3$ & $3 \pm 0.4$ & 0.001 \\
\hline Follow-up & $1.9 \pm 0.9$ & $2.1 \pm 0.8$ & 0.26 \\
\hline \multicolumn{4}{|l|}{ Diameter stenosis $(\%)$} \\
\hline Pre & $96.6 \pm 7.9$ & $96.8 \pm 7.4$ & 0.90 \\
\hline Post & $11.6 \pm 5$ & $8.7 \pm 5.4$ & 0.02 \\
\hline Follow-up & $38.7 \pm 26$ & $35.4 \pm 21.1$ & 0.53 \\
\hline \multicolumn{4}{|l|}{ Luminal changes } \\
\hline Acute gain $(\mathrm{mm})$ & $2.7 \pm 0.4$ & $2.9 \pm 0.4$ & 0.004 \\
\hline Relative acute gain & $0.8 \pm 0.1$ & $0.9 \pm 0.1$ & 0.13 \\
\hline Late loss (mm) & $0.9 \pm 0.8$ & $0.9 \pm 0.6$ & 0.73 \\
\hline Relative late loss & $0.3 \pm 0.3$ & $0.3 \pm 0.2$ & 0.88 \\
\hline Loss index & $0.3 \pm 0.3$ & $0.3 \pm 0.2$ & 0.93 \\
\hline Net gain (mm) & $1.8 \pm 0.9$ & $2 \pm 0.77$ & 0.24 \\
\hline Relative net gain & $0.6 \pm 0.3$ & $0.6 \pm 0.2$ & 0.50 \\
\hline Restenosis & $5(12.2 \%)$ & $5(12.2 \%)$ & 1 \\
\hline Reocclusion & $4(9.8 \%)$ & $2(4.9 \%)$ & 0.34 \\
\hline
\end{tabular}

nary stent implantation with balloon-pressure $>11$ atm promotes similar late clinical and angiographical results, if an optimal stent implantation is obtained.

It is interesting to compare the late loss index results between AMI and non-AMI stenting cases (non-AMI, 0.4 \pm 0.6 and AMI, $0.3 \pm 0.4$ ). This difference is justified by the way the late loss index is obtained. Its result is the division of the acute gain with the late lumen loss. In AMI cases, the majority of the vessels were found to be occluded (MLD = $0.1 \pm 0.2 \mathrm{~mm}$ ), so the acute gain in the MLD is higher than that in non-AMI patients ( $>1 \mathrm{~mm}$ ). At the follow-up, late loss is around $1 \mathrm{~mm}$ for both situations, but with a greater acute lumen gain; in AMI stenting, the late loss index is diminished.

The study had some limitations. The sample size may be understimated. The reason for this was the absence, in 1998, of AMI stenting experience reporting the effects of the balloon-pressure inflation in the late loss index ${ }^{25}$. The results of the larger STENT PAMI trial were only published in $1999^{19}$. At the end of this investigation, the late loss index was smaller than expected. Future research analyzing this variable may require more rigorous criteria regarding the sample size calculation. The patients were included in a nonrandomized fashion, also related to temporal trends regarding primary coronary stenting in AMI. Two major international randomized series recommend the systematic use of high pressure for coronary stent implantation in AMI (STENT PAMI, >16 atm and CADILLAC, $>15 \mathrm{~atm}$ ), to avoid subacute stent thrombosis. So, we left that decision to the operator at the time of the index procedure, leaving him free to obtain the best acute results achievable. The progressive change in procedural technique is clearly seen as the recruitment evolved (fig. 1) After the STENT PAMI subana- 
lysis and this series, future studies may recruit patients in a randomized way, seeing that the safety limits now are more clearly determined.

These results allowed the conclusion that the systematic use of high-pressure balloon inflation (>16 atm) during primary coronary stent implantation is not necessary. A strong recommendation is the obtainment of an optimal angiographic result $(\% \mathrm{E} \leq 10 \%)$, guided by an objective method of analysis, such as the quantitative coronary angiography.
The 2 different stent implantation strategies achieved similar rates of reestablishment of TIMI-3 flow. Patients in whom high-pressures were used ( $\geq 16$ to $\leq 20 \mathrm{~atm}$ ) had significant acute lumen gain when compared with those who received moderate balloon pressure inflations $(\geq 12$ to $<16 \mathrm{~atm}$ ). However, high pressures for primary coronary stent implantation ( $\geq 16 \mathrm{~atm}$ ) did not result in significantly better late clinical and angiographic results, either in the target-vessel revascularization, in-stent restenosis rates, or nor in the late loss index and in the net lumen gain.

\section{References}

1. Kastrati A, Schomig A, Elezi S, et al. Predictive factors of restenosis after coronary stent placement. J Am Coll Cardiol 1997; 30: 1428-36.

2. Mercado N, Boersma E, Wijns W, et al. Clinical and quantitative coronary angiographic predictors of coronary restenosis: a comparative analysis from the balloon-to-stent era. J Am Coll Cardiol 2001; 38: 645-52.

3. Abizaid A, Kornowski R, Mintz GS, et al. The influence of diabetes mellitus on acute and late clinical outcomes following coronary stent implantation. J Am Coll Cardiol 1998; 32: 584-9.

4. Elezi S, Kastrati A, Neumann FJ, Hadamitzky M, Dirschinger J, Schomig A. Vessel size and long-term outcome after coronary stent placement. Circulation 1998; 98: $1875-80$.

5. Kuntz RE, Safian RD, Carozza JP, et al. The importance of acute luminal diameter in determining restenosis after coronary atherectomy or stenting. Circulation 1992; 86: 1827-35.

6. Kuntz RE, Gibson CM, Nobuyoshi M, Baim D. Generalized model of restenosis after conventional balloon angioplasty, stenting and directional atherectomy. J Am Coll Cardiol 1993; 21: 15-25.

7. Hoffmann R, Mintz GS, Dussailant GR, et al. Patterns and mechanisms of in-stent restenosis: a serial intravascular ultrasound study. Circulation 1997; 94: 1247-54.

8. Goldberg SL, Loussararian A, De Gregorio J, et al. Predictors of diffuse and aggressive intra-stent restenosis. J Am Coll Cardiol 2001; 37: 1019-25.

9. Hoffmann R, Mintz GS, Mehran R, et al. Tissue proliferation within and surrounding Palmaz-Schatz stents is dependent on the aggressiveness of stent implantation technique. Am J Cardiol 1999; 83: 1170-4.

10. Colombo A, Hall P, Nakamura S, et al. Intracoronary stenting without anticoagulation accomplished with intravascular ultrasound guidance. Circulation 1995; 91: 1676-88.

11. Finci L, Ferraro M, Kobayashi Y, et al. Coronary stent implantation throughtout technical evolution: immediate and follow-up results. Int J Cardiovasc Interventions 1998; 1: 29-39.

12. Schwartz RS, Huber KC, Murphy JG, et al. Restenosis and the proportional neointimal response to coronary artery injury: results in a porcine model. J Am Coll Cardiol 1992; 19: 267-74.

13. Carter AJ, Laird JR, Farb A, Kufs W, Wortham DC, Virmani R. Morphologic characteristics of lesion formation and time course of smooth muscle cell proliferation in a porcine proliferative restenosis model. J Am Coll Cardiol 1994; 24: 1398-405.

14. Gorge G, Haude M, Ge J, et al. Intravascular ultrasound after low and high inflation pressure coronary artery stent implantation. J Am Coll Cardiol 1995; 26: 725-30.

15. Grines CL, Cox DA, Stone GW, et al. Coronary angioplasty with or without stent implantation for acute myocardial infarction. Stent Primary Angioplasty in Myocardial Infarction Study Group. N Engl J Med 1999; 341: 1949-56.

16. Stone GW, Grines CL, Cox D, et al. A prospective, randomized trial comparing balloon angioplasty with or without abciximab to primary stenting with or without abciximab in acute myocardial infarction: primary endpoint analysis from the CADILLAC trial. Circulation 2000; 102: II-664 (abstract).

17. Mattos LA, Grines CL, Cox D, et al. A comparative analysis of primary stenting and optimal balloon coronary angioplasty in acute myocardial infarction: six month results from the STENT PAMI trial. Arq Bras Cardiol 2000; 75: 499-514.

18. Leite RS, Krepsky AM, Gottschall CAM. Effectiveness of primary angioplasty in the treatment of acute myocardial infarction: analysis of in-hospital and late outcomes in 135 consecutive cases. Arq Bras Cardiol 2001; 77: 213-20.

19. Mattos LA, Grines C, Sousa JE, et al. Influence of maximum inflation pressure after primary stenting in acute myocardial infarction: 30 day and 6 month outcomes from the STENT PAMI trial. Circulation 1999; 100: I-856 (abstract).
20. Goldberg SL, Di Mario C, Hall P, Colombo A. Comparison of aggressive versus nonaggressive balloon dilatation for stent deployment on late loss and restenosis in native coronary arteries. Am J Cardiol 1998; 81: 708-12.

21. Yang P, Gyongyosi M, Hassan A, et al. Short-and long-term outcomes of Wiktor stent implantation at low versus high pressures. Austrian Wiktor Stent Study Group. Am J Cardiol 1999; 84: 644-9.

22. Uretsky BF, Rosanio S, Lerakis S, et al. A prospective evaluation of angiography-guided coronary stent implantation with high versus very high balloon inflation pressure. Am Heart J 2000; 140: 804-12.

23. Bermejo J, Botas J, Garcia E, et al. Mechanisms of residual lumen stenosis after high-pressure stent implantation: a quantitative coronary angiography and intravascular ultrasound study. Circulation 1998; 98: 112-8.

24. Park SW, Hong MK, Lee CW, et al. Immediate and late clinical and angiographic outcomes after GFX coronary stenting: is high-pressure balloon dilatation necessary? Clin Cardiol 2000; 8: 595-9.

25. Dirschinger J, Kastrati A, Neumann FJ, et al. Influence of balloon pressure during stent placement in native coronary arteries on early and late angiographic and clinical outcome: a randomized evaluation of high-pressure inflation. Circulation 1999; 100: 918-23.

26. Caixeta AM, Brito FS, Rati M, et al. High versus low-pressure balloon inflation during multilink stent implantation: acute and long-term angiographic results. Cathet Cardiovasc Intervent 2000; 50: 398-401.

27. Mattos LA, Pinto I, Abizaid A, et al. Safety and efficacy of coronary stent implantation: acute and six month outcomes of 1.126 consecutive patients treated in 1996 and 1997. Arq Bras Cardiol 1999; 73: 23-36.

28. Reiber JHC, Van Der Zwet PMJ, Konning G, et al. Accuracy and precision of quantitative digital coronary arteriography: observer-, short-, and medium-term variabilities. Cathet Cardiovasc Diagn 1993; 28: 187-98.

29. Pinto IMF, Sousa AGMR, Feres F, et al. The usefulness of digital angiography in performing coronary angioplasty: an analysis of 100 cases. Arq Bras Cardiol 1992; 59: 255-9.

30. Lansky AJ, Popma JJ. Qualitative and quantitative angiography. In: Topol EJ, $3^{\text {th }}$ Ed. Textbook of Interventional Cardiology. Philadelphia: WB Saunders Co., 1999: 725-42.

31. The Thrombolysis in Myocardial Infarction (TIMI) trial. Phase I findings. TIMI Study Group. N Engl J Med 1985; 312: 932-6.

32. Brener SJ, Barr LA, Burchenal JE, et al. Randomized, placebo-controlled trial of platelet glycoprotein IIb/IIIa blockade with primary angioplasty for acute myocardial infarction. ReoPro and Primary PTCA Organization and Randomized Trial (RAPPORT) Investigators. Circulation 1998; 98: 734-41.

33. THE ERASER INVESTIGATORS. Acute platelet inhibition with abciximab does not reduce in-stent restenosis (ERASER study). Circulation 1999; 100: 799-806.

34. Neumann FJ, Kastrati A, Schmitt C, et al. Effect of glycoprotein IIb/IIIa receptor blockade with abciximab on clinical and angiographic restenosis rate after the placement of coronary stents following acute myocardial infarction. J Am Coll Cardiol 2000; 35: 915-21.

35. Montalescot G, Barragan P, Wittenberg O, et al. Platelet glycoprotein IIb/IIIa inhibition with coronary stenting for acute myocardial infarction. N Engl J Med 2001; 344: 1895-903.

36. Lansky AJ, Roubin GS, O'Shaughnessy CD, et al. Randomized comparison of GR-II stent and Palmaz-Schatz stent for elective treatment of coronary stenoses. Circulation 2000; 102: 1364-8.

37. Escaned J, Goicolea J, Alfonso F, et al. Propensity and mechanisms of restenosis in different coronary stent designs: complementary value of the analysis of the luminal gain-loss relationship. J Am Coll Cardiol 1999; 34: 1490-7. 
38. Tanajura LF, Pinto IM, Mattos LA, et al. Percutaneous handling of coronary lesions $>20 \mathrm{~mm}$ through stents: is there a first choice strategy? Arq Bras Cardiol 1999; 73: 331-8.

39. Kobayashi Y, De Gregorio J, Kobayashi N, et al. Stented segment length as an independent predictor of restenosis. J Am Coll Cardiol 1999; 34: 651-9.

40. Serruys PW, Kay IP, Disco C, et al. Periprocedural quantitative coronary angiography after Palmaz-Schatz stent implantation predicts the restenosis rate at six months: results of a meta-analysis of the BElgian NEtherlands Stent study (BENESTENT) I, BENESTENT IIPilot, BENESTENT II and MUSIC trials. Multicenter Ultrasound Stent In Coronaries. J Am Coll Cardiol 1999; 34: 1067-74.

41. De Feyter PJ, Kay P, Disco C, Serruys PW. Reference chart derived from post- stent-implantation intravascular ultrasound predictors of 6-month expected restenosis on quantitative coronary angiography. Circulation 1999; 100: 1777-83.

42. Hanekamp CE, Koolen JJ, Pijls NH, Michels HR, Bonnier HJ. Comparison of quantitative coronary angiography, intravascular ultrasound, and coronary pressure measurement to assess optimum stent deployment. Circulation 1999; 99: 1015-21.

43. Bruining N, Sabate M, De Feyter PJ, et al. Quantitative measurements of in-stent restenosis: A comparison between quantitative coronary ultrasound and quantitative coronary angiography. Cathet Cardiovasc Intervent 1999; 48: 133-42.

44. Stone GW, St Goar FG, Hodgson JM, et al. Analysis of the relation between stent implantation pressure and expansion. Optimal Stent Implantation (OSTI) Investigators. Am J Cardiol 1999; 83: 1397-400. 